https://doi.org/10.15407/ujpe66.6.489

A.I. POGODIN, I.O. SHENDER, S.M. BEREZNYUK, M.Y. FILEP, O.P. KOKHAN, L.M. SUSLIKOV, I.P. STUDENYAK

Uzhhorod National University

(46, Pidhirna Str., Uzhhorod, Ukraine; e-mail: studenyak@dr.com)

\title{
STRUCTURE AND ELECTRICAL PROPERTIES OF SUPERIONIC CERAMICS BASED ON SILVER-ENRICHED $\left(\mathrm{Cu}_{0.25} \mathrm{Ag}_{0.75}\right)_{7} \mathrm{SiS}_{5} \mathrm{I}$ SOLID SOLUTION
}

\begin{abstract}
$\left(C u_{0.25} A g_{0.75}\right)_{7} S_{S} S_{5}$ I-based superionic ceramics were fabricated by using the micro- and nanopowders. The XRD technique and microstructural analysis are applied for the structural studies of powders and ceramic samples. The impedance measurements of ceramic samples are carried out in the frequency range from $10 \mathrm{~Hz}$ to $2 \times 10^{6} \mathrm{~Hz}$ and temperature interval from $292 \mathrm{~K}$ to $383 \mathrm{~K}$. The contributions of ionic and electronic conductivities into the total electrical conductivity are determined, and their temperature dependences are investigated. The influence of the size effect on ionic and electronic conductivities and their activation energies in $\left(\mathrm{Cu}_{0.25} \mathrm{Ag}_{0.75}\right)_{7} \mathrm{SiS}_{5}$ I-based ceramics is studied.

Keywords: argyrodite, superionic conductor, ceramic, ionic conductivity, activation energy.
\end{abstract}

\section{Introduction}

Ceramic materials are widely used due to their unique structural, mechanical, chemical, and functional properties. High melting temperatures, high values of the modulus of elasticity, high hardness, and low thermal expansion of ceramic materials do not limit the scope of ceramics use to solve engineering problems, but also extend them [1]. Currently, ceramic materials are used in the field of biochemistry [2], optics [3], thermoelectricity [4], electronics and electrochemistry [5]. Nowadays, the research on electrochemical ceramic materials related to the study and improvement of electrochemical energy storage technologies has been significantly promoted [6]. The active improvement of this technology is caused by the development of alternative energy sources and electric vehicles, as well as the growth of the number of portable

(c) A.I. POGODIN, I.O. SHENDER, S.M. BEREZNYUK, M.Y. FILEP, O.P. KOKHAN, L.M. SUSLIKOV, I.P. STUDENYAK, 2021

ISSN 2071-0194. Ukr. J. Phys. 2021. Vol. 66, No. 6 electronic devices [7]. Electrochemical capacitors (supercapacitors), batteries, and fuel cells are used as electrochemical energy storage devices [6]. Li-ion batteries containing a liquid organic electrolyte have become the most commercially widespread [8]. However, the combination of chemically active lithium and a flammable liquid reduces the safety of the device [9]. When using a solid electrolyte instead of a liquid one, it is possible to increase the safety of batteries, as well as to simplify their design [7, 10, 11]. Solid electrolytes, which can be used in all-solidstate batteries (ASSB), are conventionally divided into three groups: inorganic (crystal or glass-ceramic) substances, organic polymers, and hybrids. Oxides, phosphates, and sulfides are used as functional solid inorganic materials [10, 11]. Since the efficiency of batteries directly depends on the properties of the working material, so the search for and improvement of new materials is relevant. Sulfur-containing solid electrolytes attract considerable attention due to a high ionic conductivity, which is provided by the pe- 
culiarities of their crystal structure [7, 10, 12, 13], among which one should mention phosphorus sulfides $\mathrm{Li}^{+}$and $\mathrm{Na}^{+}$. As usual, sulfur-containing superionic compounds with ionic conductivity by $\mathrm{Li}^{+}$and $\mathrm{Na}^{+}$ are difficult to obtain in the crystal state [13], so they are obtained in the glass-ceramic form $[12,13]$. Promising superionic materials in this regard are also presented by the compounds with the structure of argyrodite, which are characterized by high values of ionic conductivity [14-16]. It should be noted that, in recent years, Li-containing argyrodites have been actively studied [17-20], as well as methods for obtaining argyrodites in various forms, including the form of ceramic samples [21-24]. That is why this paper is devoted to the production and to study of the structural and electrical properties of superionic ceramics based on a silver-enriched $\left(\mathrm{Cu}_{0.25} \mathrm{Ag}_{0.75}\right)_{7} \mathrm{SiS}_{5} \mathrm{I}$ solid solution.

\section{Experimental}

$\left(\mathrm{Cu}_{0.25} \mathrm{Ag}_{0.75}\right)_{7} \mathrm{SiS}_{5} \mathrm{I}$ solid solution belongs to the $\mathrm{Cu}_{7} \mathrm{SiS}_{5} \mathrm{I}-\mathrm{Ag}_{7} \mathrm{SiS}_{5} \mathrm{I}$ superionic system. It was synthesized by the direct one-temperature method from previously obtained $\mathrm{Cu}_{7} \mathrm{SiS}_{5} \mathrm{I}$ and $\mathrm{Ag}_{7} \mathrm{SiS}_{5} \mathrm{I}$ compound in quartz ampoules vacuumized to $0.13 \mathrm{~Pa}$. The synthesis process was performed in the following way: heating up to $1023 \mathrm{~K}$ at a rate of $100 \mathrm{~K} / \mathrm{h}$ (ageing during $48 \mathrm{~h}$ ), further increase of temperature to $1470 \mathrm{~K}$ at a rate of $50 \mathrm{~K} / \mathrm{h}$ and ageing at this temperature for $72 \mathrm{~h}$. The annealing of the synthesized samples was performed after lowering the temperature at a rate of $50 \mathrm{~K} / \mathrm{h}$ from a maximum of $1470 \mathrm{~K}$ to $873 \mathrm{~K}$ (annealing time was $120 \mathrm{~h}$ ), followed by the cooling to room temperature in the oven-off mode. For ceramic samples, the powders with different size of crystallites were utilized. First of all, the microcrystalline powders were obtained by the grinding in an agate mortar with an average particle size of $\sim 10-50 \mu \mathrm{m}$. Second, the nanocrystalline powders were obtained by the grinding in a planetary ball mill PQ-N04 for $30 \mathrm{~min}$ and $60 \mathrm{~min}$ with a speed of $200 \mathrm{rpm}$. Then $\left(\mathrm{Cu}_{0.25} \mathrm{Ag}_{0.75}\right)_{7} \mathrm{SiS}_{5} \mathrm{I}$ micro- and nanopowders were studied by the XRD technique (DRON 4-07 with $\mathrm{CuK} \alpha$ radiation, angle scanning speed $2 \theta$ is 0.02 degree, exposure is $1 \mathrm{~s}$ ) and scanning electron microscopy (SEM). Further, the powders were pressed at $\sim 400 \mathrm{MPa}$ and annealed at $973 \mathrm{~K}$ during $36 \mathrm{~h}$. The heating of the pressed samples to a temperature of $973 \mathrm{~K}$ and the subsequent cooling to room tempera- ture were performed at a rate of $10 \mathrm{~K} / \mathrm{h}$. As a result, polycrystalline ceramic samples were obtained in the form of disks with a diameter of $8 \mathrm{~mm}$ and a thickness of 3-4 mm. To determine the size of crystallites after the annealing, the ceramic samples were investigated by microstructural analysis using a metallographic microscope METAM-R1. The electrical conductivity of ceramic samples was measured by the impedance spectroscopy method [25] in the frequency ranges $\left(10 \mathrm{~Hz}-3 \times 10^{5} \mathrm{~Hz} ; 20 \mathrm{~Hz}-2 \times 10^{6} \mathrm{~Hz}\right)$ and the temperature interval (292-383 K) with combination of high-precision LCR meters: Keysight E4980A and AT-2818. The amplitude of the alternating current constituted $10 \mathrm{mV}$. Measurement was carried out by the two-electrode method, on blocking (electronic) gold contacts. Gold contacts for measurements were applied by chemical precipitation from solutions [26].

\section{Results and Discussion \\ 3.1. Structural studies \\ of $\left(\mathrm{Cu}_{0.25} A g_{0.75}\right)_{7} \mathrm{SiS}_{5} \mathrm{I}$ solid solution}

$\left(\mathrm{Cu}_{0.25} \mathrm{Ag}_{0.75}\right)_{7} \mathrm{SiS}_{5} \mathrm{I}$ solid solution crystalizes in facecentered cubic cells with (space group F-43m, the number of formula units per unit cell $Z=4$ ) the lattice parameter $a=10.4093$ (4) $\AA$ (Fig. 1, a). Due to the isostructurality of $\mathrm{Cu}_{7} \mathrm{SiS}_{5} \mathrm{I}$ and $\mathrm{Ag}_{7} \mathrm{SiS}_{5} \mathrm{I}$ compounds and close values of ion radii $\left(0.98 \AA\right.$ for $\mathrm{Cu}^{+}$ and $1.13 \AA$ for $\mathrm{Ag}^{+}$[27]), the $\left(\mathrm{Cu}_{0.25} \mathrm{Ag}_{0.75}\right)_{7} \mathrm{SiS}_{5} \mathrm{I}$ solid solution is formed in $\mathrm{Cu}_{7} \mathrm{SiS}_{5} \mathrm{I}-\mathrm{Ag}_{7} \mathrm{SiS}_{5} \mathrm{I}$ system. The refinements of the $\mathrm{Cu}^{+} \leftrightarrow \mathrm{Ag}^{+}$substitution mechanism and lattice atomic coordinates were conducted on the basis of the refined models of original structures by means of the Rietveld method [28]. Model calculation and refinement were performed using the EXPO 2014 software [29], the visualization was done in the VESTA 3.5.2 program [30]. In order to explain the structural changes at the $\mathrm{Cu}^{+} \leftrightarrow \mathrm{Ag}^{+}$ substitution, we will consider $\left[\mathrm{Cu}(\mathrm{Ag}) \mathrm{S}_{3} \mathrm{I}_{2}\right]$ doubled tetrahedra. During the solid solution formation, the silver substitution occurs both in $\mathrm{Cu} 1(24 \mathrm{~g})$ and $\mathrm{Cu} 2(48 \mathrm{~h})$ positions and is accompanied by shifts in positions and by the creation of Cu1Ag1 and Cu2Ag2 joint positions. The joint position of Cu1Ag1 is located in the S1S2S1 triangle plane, but due to the increasing of the $\mathrm{Cu} 1-\mathrm{Ag} 1$ distance up to $0.661 \AA$, the atom in $\mathrm{Cu} 1$ position is shifted to the S1S1 edge. At the same time, the dynamics of a strong elongation of the $\mathrm{Cu}_{2} \mathrm{Ag}_{2}$ substitution position (Cu2-Ag2 distances are $1.809 \AA$ ) is observed. This causes a shifting 

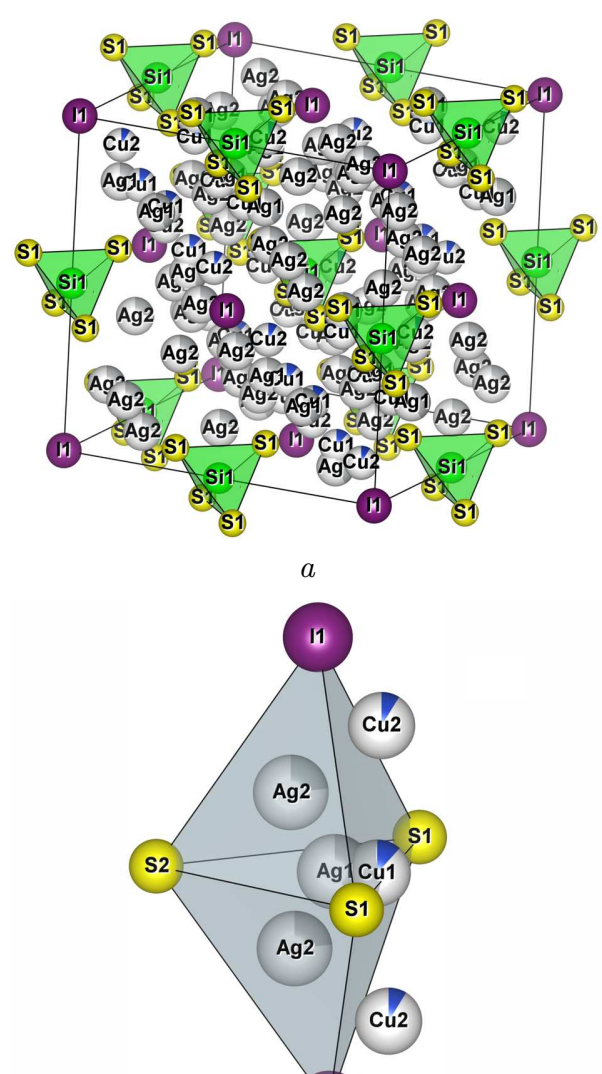

I1

$b$

Fig. 1. Structure of a cubic cell $(a)$ and the $\mathrm{Cu}^{+} \leftrightarrow \mathrm{Ag}^{+}$replacement dynamics during the formation of $\left(\mathrm{Cu}_{0.25} \mathrm{Ag}_{0.75}\right)_{7} \mathrm{SiS}_{5} \mathrm{I}$ solid solution as exemplified by $\left[\mathrm{S}_{3} \mathrm{I}_{2}\right]$ doubled tetrahedra $(b)$

of the atom at the $\mathrm{Cu} 2$ position beyond the double tetrahedron $\left[\mathrm{Cu}(\mathrm{Ag}) \mathrm{S}_{3} \mathrm{I}_{2}\right]$ (Fig. 1, b), which, in turn, affects the deviation from the tetrahedral coordination. At the same time Ag2 atom is displaced from IS2 edge and the planes of triangles (S1I1S2) inside the tetrahedron [S1S2S1I1], i.e., it acquires the tetrahedral coordination, but with a shift to the corresponding triangle (S1I1S2) (Fig. 1, b). From the above, we can conclude that $\mathrm{Cu}^{+} \leftrightarrow \mathrm{Ag}^{+}$causes a strong disordering of the cationic sublattice in comparison with $\mathrm{Cu}_{7} \mathrm{SiS}_{5} \mathrm{I}$ and $\mathrm{Ag}_{7} \mathrm{SiS}_{5} \mathrm{I}$. X-ray diffractograms for $\left(\mathrm{Cu}_{0.25} \mathrm{Ag}_{0.75}\right)_{7} \mathrm{SiS}_{5} \mathrm{I}$ micro- and nanopowders are shown in Fig. 2. It is observed that XRD patterns for $\left(\mathrm{Cu}_{0.25} \mathrm{Ag}_{0.75}\right)_{7} \mathrm{SiS}_{5} \mathrm{I}$ micro- and nanopowders are typical of argyrodite structures [26]. However, the broadening of lines occurs with a decrease in the

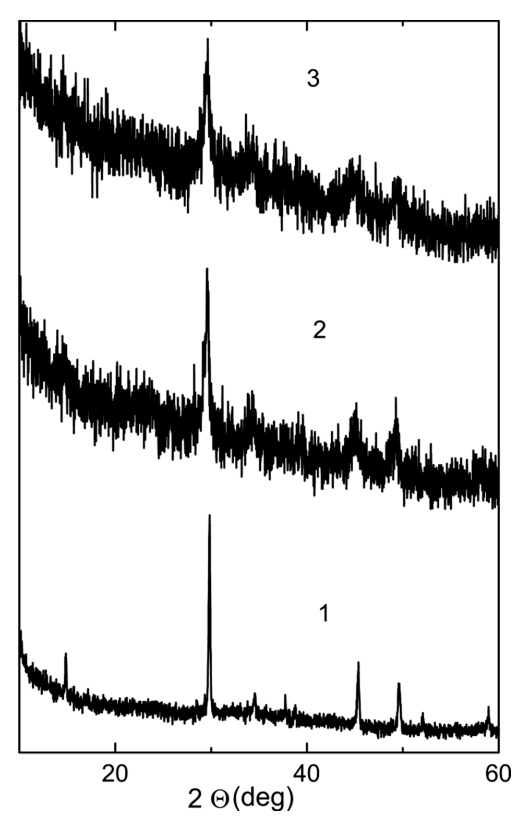

Fig. 2. Diffractograms of $\left(\mathrm{Cu}_{0.25} \mathrm{Ag}_{0.75}\right)_{7} \mathrm{SiS}_{5} \mathrm{I}$ powders obtained by the grinding in agate mortar (1) and a planetary ball mill for $30 \mathrm{~min}(2)$ and $60 \mathrm{~min}(3)$

size of particles (Fig. 2). It is established from SEMstudies that, at the grinding (in a planetary ball mill) for $30 \mathrm{~min}$, the average size of particles is $\sim 150 \mathrm{~nm}$, while it comprises $\sim 100 \mathrm{~nm}$ at the 60 -min grinding. As a result of the microstructural analysis, the histograms of the distributions of the sizes of crystallites for different $\left(\mathrm{Cu}_{0.25} \mathrm{Ag}_{0.75}\right)_{7} \mathrm{SiS}_{5}$ I-based ceramics were constructed (Fig. 3). It is shown that the average size of crystallites for the ceramic sample obtained from a micropowder is equal to $\sim 12 \mu \mathrm{m}$, while, for nanopowders obtained by the grinding in a planetary ball mill for $30 \mathrm{~min}$ and $60 \mathrm{~min}$, these sizes equal $\sim 5 \mu \mathrm{m}$ and $\sim 3 \mu \mathrm{m}$, respectively.

\subsection{Electrical studies of $\left(\mathrm{Cu}_{0.25} \mathrm{Ag}_{0.75}\right)_{7} \mathrm{SiS}_{5}$ I-based ceramics}

The frequency dependences of the total electrical conductivity for $\left(\mathrm{Cu}_{0.25} \mathrm{Ag}_{0.75}\right)_{7} \mathrm{SiS}_{5} \mathrm{I}$-based ceramics are presented in Fig. 4. It is shown that, similarly to $\left(\mathrm{Cu}_{0.25} \mathrm{Ag}_{0.75}\right)_{7} \mathrm{SiS}_{5} \mathrm{I}$ mixed crystal, the electrical conductivity of $\left(\mathrm{Cu}_{0.25} \mathrm{Ag}_{0.75}\right)_{7} \mathrm{SiS}_{5} \mathrm{I}$-based ceramics grows with the frequency, which is typical of materials with ionic conductivity in the solid state [31]. In addition, the carried out measurements allowed us to study the influence of the size effect on the electrical conductivity. Thus, a decrease of the size of crystal- 


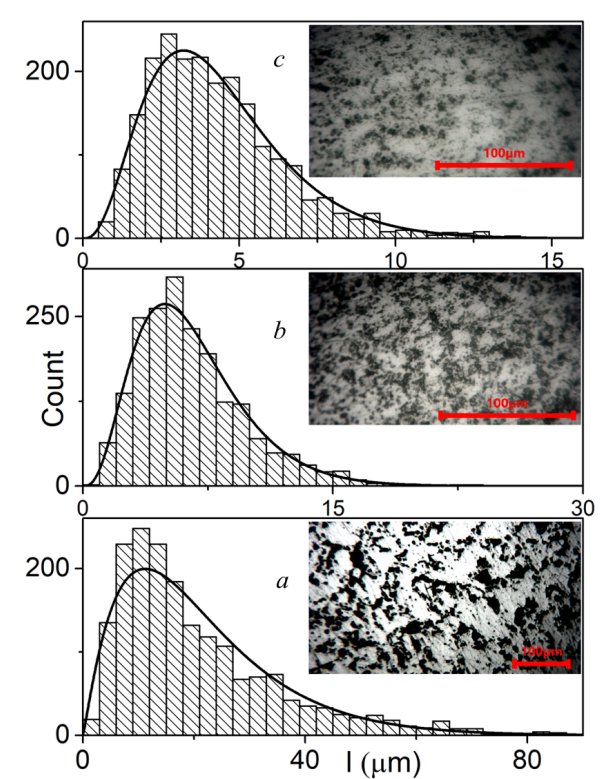

Fig. 3. Dependences of size distribution for crystallites of $\left(\mathrm{Cu}_{0.25} \mathrm{Ag}_{0.75}\right)_{7} \mathrm{SiS}_{5} \mathrm{I}$-based ceramics obtained from powders which were milled in an agate mortar $(a)$ and a planetary ball mill for $30 \mathrm{~min}(b)$ and $60 \mathrm{~min}(c)$. The inserts show the microstructure images for different $\left(\mathrm{Cu}_{0.25} \mathrm{Ag}_{0.75}\right)_{7} \mathrm{SiS}_{5} \mathrm{I}$-based ceramics



Fig. 4. Frequency dependences of the total electrical conductivity at $T=298 \mathrm{~K}$ for $\left(\mathrm{Cu}_{0.25} \mathrm{Ag}_{0.75}\right)_{7} \mathrm{SiS}_{5} \mathrm{I}$-based ceramics with different sizes of crystallites: (1) $12 \mu \mathrm{m}$; (2) $5 \mu \mathrm{m}$; (3) $3 \mu \mathrm{m}$. The insert shows the dependence of the total electrical conductivity on the size of crystallites at $100 \mathrm{kHz}$

lites from $12 \mu \mathrm{m}$ to $5 \mu \mathrm{m}$ leads to a slight increase of the total electrical conductivity, while the change of the size of crystallites from $5 \mu \mathrm{m}$ to $3 \mu \mathrm{m}$ leads to a decrease of the total electrical conductivity (insert to Fig. 4). For detailed studies of the total electrical conductivity, the electrode equivalent circuits (EEC) were used [32], and a further analysis of the Nyquist
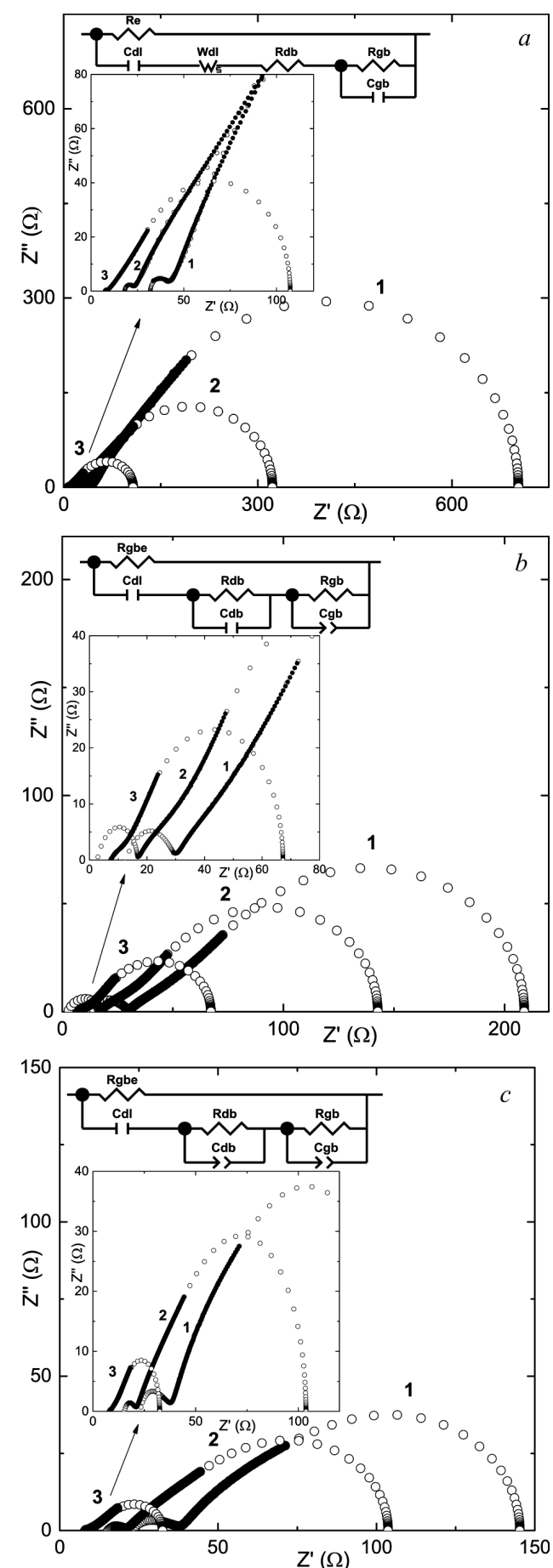

Fig. 5. EEC and Nyquist plots for $\left(\mathrm{Cu}_{0.25} \mathrm{Ag}_{0.75}\right)_{7} \mathrm{SiS}_{5} \mathrm{I}-$ based ceramics with different crystallite sizes: (a) $12 \mu \mathrm{m} ;(b)$ $5 \mu \mathrm{m}$; (c) $3 \mu \mathrm{m}$ for temperatures (1) $298 \mathrm{~K}$, (2) $323 \mathrm{~K}$, (3) $373 \mathrm{~K}$. Experimental data correspond to the solid dots, calculated data correspond to the open dots

ISSN 2071-0194. Ukr. J. Phys. 2021. Vol. 66, No. 6 
plots was performed. The parasitic inductance of the cell $\left(2 \times 10^{-8} \mathrm{H}\right)$ is taken into account during the analysis of all ceramics. At $Z^{\prime}-Z^{\prime \prime}$ dependences for $\left(\mathrm{Cu}_{0.25} \mathrm{Ag}_{0.75}\right)_{7} \mathrm{SiS}_{5} \mathrm{I}$-based ceramics with the average size of crystallites to be $12 \mu \mathrm{m}$ and $3 \mu \mathrm{m}$, two semicircles are observed, while, for ceramics with the average size of crystallites to be $5 \mu \mathrm{m}$, three semicircles are revealed (Fig. 5). It should be noted that EEC, which describe the Nyquist plots, can be divided in two parts: one of them relates to ionic processes, another one to electronic processes. The low-frequency semicircles on the Nyquist plots correspond to the diffusion relaxation processes at the electrode/crystal boundary which is described by the capacity of the double diffusion layer $C_{\mathrm{dl}}$ with serial included elements with $R_{\mathrm{gb}} / C_{\mathrm{gb}}$ parameters which are related to the resistance and capacity of the grain boundaries of ceramic samples (the end of low-frequency semicircles) (Fig. 5, $a, c$ ). The corresponding resistance $R_{\mathrm{gb}}$ with the parallel capacity $C_{\mathrm{gb}}$ is related to the appearance of a smeared mid-frequency semicircle for $\left(\mathrm{Cu}_{0.25} \mathrm{Ag}_{0.75}\right)_{7} \mathrm{SiS}_{5} \mathrm{I}$-based ceramics with the average size of crystallites equal to $5 \mu \mathrm{m}$ (Fig. $5, b$ ). In addition, for $\left(\mathrm{Cu}_{0.25} \mathrm{Ag}_{0.75}\right)_{7} \mathrm{SiS}_{5} \mathrm{I}$-based ceramics with the average size of crystallites equal to $12 \mu \mathrm{m}$ (Fig. 5, a), the Warburg element of $W_{d}$ is additionally serially included in EEC, being responsible for the diffusion within the double diffusion layer. In turn, the high-frequency semicircles correspond to the conductivity processes determined by the resistance of intra-grain boundaries $R_{\mathrm{db}}$ (Fig. 5, a) with parallelly included $C_{\mathrm{db}}$ (Fig. $5, b, c$ ). Thus, the ionic conductivity of $\left(\mathrm{Cu}_{0.25} \mathrm{Ag}_{0.75}\right)_{7} \mathrm{SiS}_{5} \mathrm{I}$-based ceramics is determined by the sum of the resistance of grain boundaries $R_{\mathrm{gb}}$ with the resistance of intra-grain boundaries $R_{\mathrm{db}}$ and/or the resistance limiting the ion diffusion $W_{R}$ (for the ceramics with the average size of crystallites to be $12 \mu \mathrm{m})$. It should be noted that, on EEC in parallel to the elements responsible for ionic processes, the electronic resistance $\mathrm{R}_{e}$ is included and determined the electronic conductivity of the samples (Fig. 5, a).

\subsection{Influence of the temperature and the size of crystallites on electrical parameters of $\left(\mathrm{Cu}_{0.25} \mathrm{Ag}_{0.75}\right)_{7} \mathrm{SiS}_{5}$ I-based ceramics}

Temperature studies have shown that, with increasing the temperature, the increase of the electronic

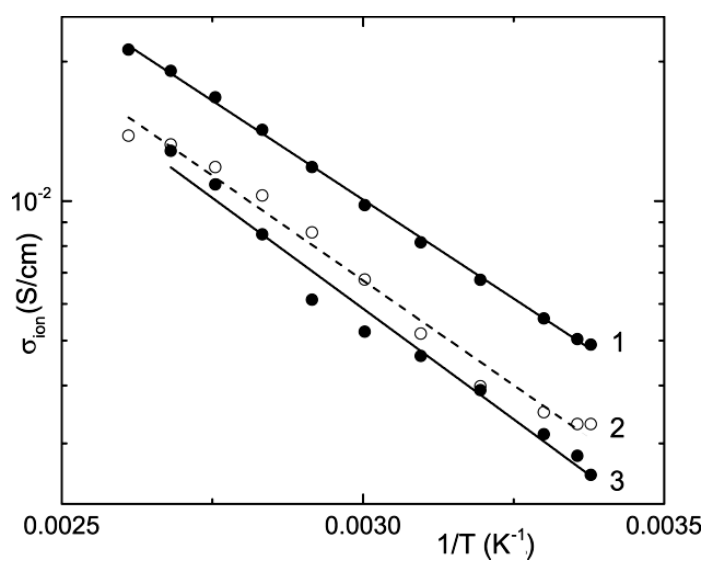

$a$



Fig. 6. Temperature dependences of ionic $(a)$ and electronic (b) components of the electrical conductivity for $\left(\mathrm{Cu}_{0.25} \mathrm{Ag}_{0.75}\right)_{7} \mathrm{SiS}_{5} \mathrm{I}$-based ceramics with different crystallite sizes: (1) $12 \mu \mathrm{m}$; (2) $5 \mu \mathrm{m}$; (3) $3 \mu \mathrm{m}$

conductivity gradually eliminates the influence of diffusion ionic processes at the boundaries of ceramic crystallites, as evidenced by a decrease of the highfrequency semicircle at $323 \mathrm{~K}$ (Fig. 5, curve 2). With a further increase of the temperature up to $373 \mathrm{~K}$ (Fig. 5, curve 3), there is a further reduction of the influence of diffusion ionic processes. This, together with the decrease in the thickness of the double diffusion layer, leads to the complete disappearance of the mid-frequency semicircle (Fig. 5, b, curve 3) and a significant decrease of the high-frequency semicircle. Figure 6 presents the temperature dependences of the ionic and electronic components of the electrical conductivity in the Arrhenius coordinates. It is shown that the observed temperature dependences are linear and described by the Arrhe- 




$a$

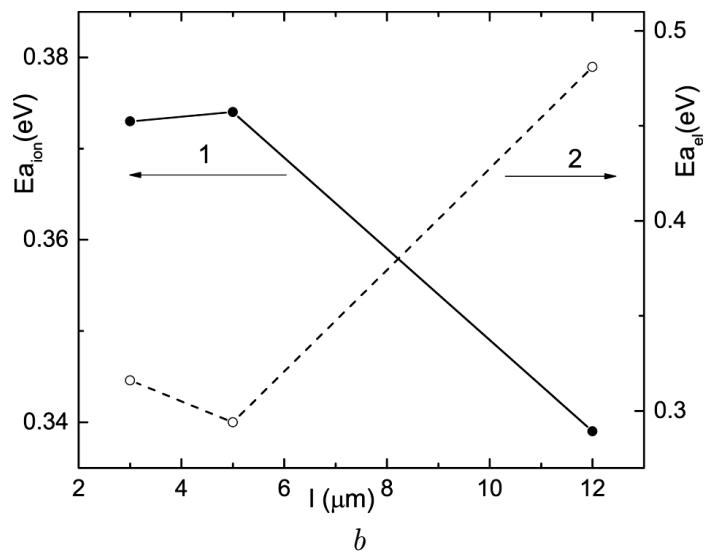

Fig. 7. (a) Dependences of the ionic (1) and electronic (2) components of the electrical conductivity at $T=298 \mathrm{~K}$ on the size of crystallites for $\left(\mathrm{Cu}_{0.25} \mathrm{Ag}_{0.75}\right)_{7} \mathrm{SiS}_{5} \mathrm{I}$-based ceramics, the insert shows the dependence of the ratio of the conductivity components on the size of crystallites; $(b)$ Dependences of the activation energy of the ionic (1) and electronic (2) components of the electrical conductivity on the size of crystallites for $\left(\mathrm{Cu}_{0.25} \mathrm{Ag}_{0.75}\right)_{7} \mathrm{SiS}_{5} \mathrm{I}$-based ceramics

nius law, which confirms the thermoactivating character of electrical conductivity. The performed analysis of the impedance spectra creates an opportunity to study the influence of the size factor on the variation of the ionic and electronic components of the electrical conductivity for $\left(\mathrm{Cu}_{0.25} \mathrm{Ag}_{0.75}\right)_{7} \mathrm{SiS}_{5} \mathrm{I}$-based ceramics. Figure 7, $a$ shows the dependences of the ionic and electronic components of the electrical conductivity on the size of crystallites in $\left(\mathrm{Cu}_{0.25} \mathrm{Ag}_{0.75}\right)_{7} \mathrm{SiS}_{5} \mathrm{I}-$ based ceramics. It is revealed that the decrease in the size of crystallites $12 \mu \mathrm{m} \rightarrow 5 \mu \mathrm{m} \rightarrow 3 \mu \mathrm{m}$ leads to a monotonous decrease of the ionic component and a monotonous increase of the electronic components of the electrical conductivity. It is well known that the ratio of the ionic conductivity to the elec- tronic one is one of the most significant parameters for superionic conductors. The insert to Fig. 7, a presents the dependence of the ratio of the conductivity components on the size of crystallites. It is seen that, for $\left(\mathrm{Cu}_{0.25} \mathrm{Ag}_{0.75}\right)_{7} \mathrm{SiS}_{5} \mathrm{I}$-based ceramics, the ratio $\sigma_{\text {ion }} / \sigma_{\text {el }}$ monotonously decreases with a decrease of the size of crystallites from $12 \mu \mathrm{m}$ to $3 \mu \mathrm{m}$. The activation energies of the ionic and electronic conductivities were determined from the temperature dependences and are shown in Fig. 7, b. It is shown that the activation energies of both components of the electrical conductivity for $\left(\mathrm{Cu}_{0.25} \mathrm{Ag}_{0.75}\right)_{7} \mathrm{SiS}_{5} \mathrm{I}$-based ceramics nonlinearly depend on the size of crystallites (Fig. 7, b). Thus, at the transition of the size of crystallites from $12 \mu \mathrm{m}$ to $5 \mu \mathrm{m}$, an increase of the activation energy of the ionic component and a decrease of the activation energy of the electronic component are observed, whereas at the transition of the size of crystallites from $5 \mu \mathrm{m}$ to $3 \mu \mathrm{m}$, a slight decrease of the activation energy of the ionic component and a slight increase of the activation energy of the electronic component are revealed. To sum up, it is of interest to compare the values of ionic and electronic conductivities, as well as their ratio for the crystal and $\left(\mathrm{Cu}_{0.25} \mathrm{Ag}_{0.75}\right)_{7} \mathrm{SiS}_{5}$ I-based ceramics. It is shown that the ionic and electronic conductivities for all ceramic samples are greater than that of crystal ones $\left(\sigma_{\text {ion }}=8.1 \times 10^{-4} \mathrm{~S} / \mathrm{cm}\right.$ and $\sigma_{\mathrm{el}}=1.0 \times 10^{-4} \mathrm{~S} / \mathrm{cm}$ for crystal) $[26]$. Nevertheless, the ratios $\sigma_{\mathrm{ion}} / \sigma_{\mathrm{el}}$ for all ceramic samples are less than that of crystal ones $\left(\sigma_{\text {ion }} / \sigma_{\text {el }}=7.9\right.$ for the crystal) [26]. Thus, the performed investigations have shown that $\left(\mathrm{Cu}_{0.25} \mathrm{Ag}_{0.75}\right)_{7} \mathrm{SiS}_{5} \mathrm{I}$-based ceramics possesses the high ionic conductivity, which is greater than in the corresponding crystals. It follows that the obtained $\left(\mathrm{Cu}_{0.25} \mathrm{Ag}_{0.75}\right)_{7} \mathrm{SiS}_{5} \mathrm{I}$-based ceramics is more attractive than crystals for practical applications as functional materials for creating ASSB based on them.

\section{Conclusions}

The superionic ceramics based on a silver-enriched $\left(\mathrm{Cu}_{0.25} \mathrm{Ag}_{0.75}\right)_{7} \mathrm{SiS}_{5} \mathrm{I}$ solid solution were prepared from micro- and nanopowders. Micro- and nanopowders with different sizes of particles were obtained by the grinding in an agate mortar and in a planetary ball mill. As the size of particles decreases, the X-ray diffraction lines broadening is observed. Three types 
of $\left(\mathrm{Cu}_{0.25} \mathrm{Ag}_{0.75}\right)_{7} \mathrm{SiS}_{5}$ I-based ceramic samples with different sizes of crystallites ( $3 \mu \mathrm{m}, 5 \mu \mathrm{m}$, and $12 \mu \mathrm{m})$ were studied by the microstructural analysis, which resulted in the dependences of a size distribution. The total electrical conductivity for $\left(\mathrm{Cu}_{0.25} \mathrm{Ag}_{0.75}\right)_{7} \mathrm{SiS}_{5} \mathrm{I}-$ based ceramics was measured in the frequency and temperature ranges from $10 \mathrm{~Hz}$ to $2 \times 10^{6} \mathrm{~Hz}$ and from $292 \mathrm{~K}$ to $383 \mathrm{~K}$, respectively. Based on the frequency dependences and Nyquist plots, the total electrical conductivity of $\left(\mathrm{Cu}_{0.25} \mathrm{Ag}_{0.75}\right)_{7} \mathrm{SiS}_{5} \mathrm{I}$-based ceramics was divided into ionic and electronic components. It should be noted that the ionic and electronic components, as well as their ratio $\sigma_{\text {ion }} / \sigma_{\text {el }}$, decrease with decreasing the size of crystallites in the ceramics under investigation. It is shown that the temperature dependences of ionic and electronic components are described by the Arrhenius law, which is the evidence of the thermoactivating character of the conductivity. Comparative analysis showed that the ionic conductivity of $\left(\mathrm{Cu}_{0.25} \mathrm{Ag}_{0.75}\right)_{7} \mathrm{SiS}_{5}$ I-based ceramics is greater than for the corresponding crystal, and this, in turn, can be used to create new electrochemical devices.

1. M. Bengisu. Applications of ceramic materials. In: Engineering Ceramics. Engineering Materials (Springer, 2001), p. 407-446 [ISBN: 978-3-642-08719-6, 978-3-66204350-9].

2. M. Vallet-Regí. Ceramics for medical applications. J. Chem. Soc., Dalton Trans. 2, 97 (2001).

3. Z. Xiao,S. Yu, Y. Li, S. Ruan, L.B. Kong, Q. Huang, Z. Huang, K. Zhou, H. Su, Z. Yao, W. Que, Y. Liu, T. Zhang, J. Wang, P. Liu, D. Shen, M. Allix, J. Zhang, D. Tang. Materials development and potential applications of transparent ceramics: A review. Mater. Sci. Engin.: R: Reports 139, 100518 (2020).

4. R.-Z. Zhang, M.J. Reece. Review of high entropy ceramics: Design, synthesis, structure and properties. J. Mater. Chem. A 7, 22148 (2019).

5. X. Hao. A review on the dielectric materials for high energy-storage application. J. Adv. Dielectr. 3 (1), 1330001 (2013).

6. V. Fernao Pires, E. Romero-Cadaval, D. Vinnikov, I. Roasto, J.F. Martins. Power converter interfaces for electrochemical energy storage systems - A review. Energy Conversion and Management 86, 453 (2014).

7. Z. Wu, Z. Xie, A. Yoshida, Z. Wang, X. Hao, A. Abudula, G. Guan. Utmost limits of various solid electrolytes in allsolid-state lithium batteries: A critical review. Renewable and Sustainable Energy Reviews 109, 367 (2019).

8. J.B. Goodenough, K.-S. Park. The Li-ion rechargeable battery: a perspective. J. Am. Chem. Soc. 135 (4), 1167 (2013).
9. J. Wen, Y. Yu, C. Chen. A review on lithium-ion batteries safety issues: Existing problems and possible solutions. Mater. Express 2, 197 (2012).

10. J.W. Fergus. Ceramic and polymeric solid electrolytes for lithium-ion batteries. J. Power Sources 195, 4554 (2010).

11. Z. Zhang, Q. Zhang, C. Ren, F. Luo, Q. Ma, Y.-S. Hu, Z. Zhou, H. Li, X.H., L. Chen. A ceramic/polymer composite solid electrolyte for sodium batteries. J. Mater. Chem. A 4, 15823 (2016).

12. K.H. Park, D.H. Kim, H. Kwak, S.H. Jung, H.-J. Lee, A. Banerjee, J.H. Lee, Y.S. Jung. Solution-derived glassceramic $\mathrm{NaI} \times \mathrm{Na}_{3} \mathrm{SbS}_{4}$ superionic conductors for all-solidstate Na-ion batteries. J. Mater. Chem. A 6, 17192 (2018).

13. M. Tatsumisago, A. Hayashi. Sulfide glass-ceramic electrolytes for all-solid-state lithium and sodium batteries. Int. J. Appl. Glass Sci. 5, 226 (2014).

14. W.F. Kuhs, R. Nitsche, K. Scheunemann. The argyrodites - a new family of the tetrahedrally close-packed structures. Mater. Res. Bull. 14, 241 (1979).

15. T. Nilges, A. Pfitzner. A structural differentiation of quaternary copper argirodites: Structure- property relations of high temperature ion conductors.Z. Kristallogr. 220, 281 (2005).

16. I.P. Studenyak, M. Kranjčec, M.V. Kurik. Urbach rule and disordering processes in $\mathrm{Cu}_{6} \mathrm{P}\left(\mathrm{S}_{1-x} \mathrm{Se}_{x}\right)_{5} \mathrm{Br}_{1-y} \mathrm{I}_{y}$ superionic conductors. J. Phys. Chem. Solids 67, 807 (2006).

17. H.-J. Deiseroth, S.-T. Kong, H. Eckert, J. Vannahme, C. Reiner, T. Zai $\beta$, M. Schlosser. $\mathrm{Li}_{6} \mathrm{PS}_{5} \mathrm{X}$ : A class of crystalline Li-rich solids with an unusually high $\mathrm{Li}^{+}$mobility. Angew. Chem. Int. Ed. 47, 755 (2008).

18. L. Zhou, A. Assoud, Q. Zhang, X. Wu, L.F. Nazar. New family of argyrodite thioantimonate lithium superionic conductors. J. Am. Chem. Soc. 141 (48), 19002 (2019).

19. H. Wang, C. Yu, S. Ganapathy, E.R.H. van Eck, L. van Eijck, M. Wagemaker. A lithium argyrodite $\mathrm{Li}_{6} \mathrm{PS}_{5} \mathrm{Cl}_{0.5} \mathrm{Br}_{0.5}$ electrolyte with improved bulk and interfacial conductivity. Journal of Power Sources 412, 29 (2019).

20. Wo Dum Jung, Ji-Su Kim, Sungjun Choi, Seongmin Kim, Minjae Jeon, Hun-Gi Jung, Kyung Yoon Chung, JongHo Lee, Byung-Kook Kim, Jong-Heun Lee, Hyoungchul Kim. Superionic halogen-rich Li-argyrodites using in situ nanocrystal nucleation and rapid crystal growth. Nano Lett. 20 (4), 2303 (2020).

21. A.F. Orliukas, E. Kazakevicius, A. Kezionis, T. Salkus, I.P. Studenyak, R.Yu. Buchuk, I.P. Prits, V.V. Panko. Preparation, electric conductivity and dielectrical properties of $\mathrm{Cu}_{6} \mathrm{PS}_{5} \mathrm{I}$-based superionic composites. Solid State Ionics 180, 183 (2009).

22. I.P. Studenyak, V.Yu. Izai, V.I. Studenyak, O.V. Kovalchuk, T.M. Kovalchuk, P. Kopčanský, M. Timko, N. Tomašovičová, V. Zavisova, J. Miskuf, I.V. Oleinikova. Influence of $\mathrm{Cu}_{6} \mathrm{PS}_{5} \mathrm{I}$ superionic nanoparticles on the dielectric properties of 6CB liquid crystal. Liquid Crystals 44, 897 (2017). 
23. T. S̆alkus, E. Kazakevičius, J. Banys, M. Kranjčec, A.A. Chomolyak, Yu.Yu. Neimet, I.P. Studenyak. Influence of grain size effect on electrical properties of $\mathrm{Cu}_{6} \mathrm{PS}_{5} \mathrm{I}$ superionic ceramics. Solid State Ionics 262, 597 (2014).

24. I.P. Studenyak, M.Kranjčec, V.Yu. Izai, A.A. Chomolyak, M. Vorohta, V. Matolin, C. Cserhati, S. Kökényesi. Structural and temperature-related disordering studies of $\mathrm{Cu}_{6} \mathrm{PS}_{5} \mathrm{I}$ amorphous thin films. Thin Solid Films $\mathbf{5 2 0}$ 1729 (2012).

25. M.E. Orazem, B. Tribollet. Electrochemical Impedance Spectroscopy. (Wiley, 2008).

26. I.P. Studenyak, A.I. Pogodin, V.I. Studenyak, V.Yu. Izai, M.J. Filep, O.P. Kokhan, M. Kranjčec, P.Kúš. Electrical properties of copper- and silver-containing superionic $\left(\mathrm{Cu}_{1-x} \mathrm{Ag}_{x}\right)_{7} \mathrm{SiS}_{5} \mathrm{I}$ mixed crystals with argyrodite structure. Solid State Ionics 345, 115183 (2020).

27. V.S. Urusov. Theoretical Crystallochemistry (MSU, 1987) (in Russian).

28. L.B. McCusker, R.B. Von Dreele, D.E. Cox, D. Louër, P. Scardi. Rietveld refinement guidelines. J. Appl. Crystallogr. 32, 36 (1999).

29. A. Altomare, C. Cuocci, C. Giacovazzo, A. Moliterni, R. Rizzi, N. Corriero, A. Falcicchio. EXPO2013: A kit of tools for phasing crystal structures from powder data. J. Appl. Crystallogr. 46, 1231 (2013).

30. K. Momma, F. Izumi. VESTA 3 for three-dimensional visualization of crystal, volumetric and morphology data. J. Appl. Crystallogr. 44, 1272 (2011).
31. A.K. Ivanov-Schitz, I.V. Murin. Solid State Ionics (St.Petersburg State Univ., 2000) (in Russian).

32. R.A. Huggins. Simple method to determine electronic and ionic components of the conductivity in mixed conductors: A review. Ionics 8, 300 (2002).

Received 05.06.20

А.І. Погодін, І.О. Шендер,

С.М. Березнюк, М.Й. Філеп, О.П. Кохан,

Л.М. Сусліков, І.П. Студеняк

СТРУКТУРА ТА ЕЛЕКТРИЧНІ

ВЛАСТИВОСТІ СУПЕРІОННОЇ КЕРАМІКИ

НА ОСНОВІ ЗБАГАЧЕНОГО СРІБЛОМ

ТВЕРДОГО РОЗЧИНУ $\left(\mathrm{Cu}_{0,25} \mathrm{Ag}_{0,75}\right)_{7} \mathrm{SiS}_{5} \mathrm{I}$

Отримано суперіонні керамічні зразки на основі твердого розчину $\left(\mathrm{Cu}_{0,25} \mathrm{Ag}_{0,75}\right)_{7} \mathrm{SiS}_{5} \mathrm{I} 3$ використанням мікрота нанопорошків. Для структурних досліджень порошків та керамічних зразків використано методи РФА та мікроструктурного аналізу. Імпедансні вимірювання керамічних зразків проводилися в частотному діапазоні від 10 до $2 \cdot 10^{6}$ Гц та температурному інтервалі 292-383 К. Визначено внески іонної та електронної провідностей у загальну електропровідність, досліджено іх температурні залежності. Вивчено вплив розмірного ефекту на іонну та електронну провідність та розраховано енергії активації керамічних зразків.

Ключовi слова: аргіродит, суперіонний провідник, кераміка, іонна провідність, енергія активації. 